\title{
GAMBARAN PERILAKU HIDUP SEHAT IBU YANG MEMILIKI BALITA DI WILAYAH KERJA PUSKESMAS UBUD I, KABUPATEN GIANYAR BALI TAHUN 2014
}

Yuhanantini Gopal Kishnam

Fakultas Kedokteran Universitas Udayana

\begin{abstract}
ABSTRAK
Latar belakang: Diare merupakan masalah kesehatan masyarakat di Indonesia. Pada bulan Januari hingga Desember tahun 2013, diare masih termasuk ke dalam 10 penyakit terbanyak di wilayah kerja Puskesmas Ubud I, yaitu menempati urutan ke-9 dengan jumlah 687 kasus. Prevalensi diare pada balita di wilayah kerja Puskesmas Ubud I 220 balita atau 6,1\%.
\end{abstract}

Metode Penelitian: Penelitian ini menggunakan rancangan cross sectional deskriptif. Data diperoleh dari wawancara berstruktur dengan kuisioner. Responden penelitian adalah 45 ibu yang memiliki balita yang dipilih secara simple random sampling. Data yang diperoleh dianalisis menggunakan program statistik dan disajikan dalam bentuk tabel dan naratif.

Hasil Penelitian:Sebagian besar responden $(88,9 \%)$ sudah memiliki perilaku mencuci tangan namun metode yang digunakan masih banyak yang kurang baik. Sebagian besar responden belum memiliki perilaku mencuci bahan makanan yaitu sebanyak $73,3 \%$. Sebanyak $60 \%$ responden sudah memiliki perilaku mencuci peralatan makan dan sebagian besar metode yang digunakan sudah baik. $68,9 \%$ responden memiliki perilaku merebus air dan metode sudah baik. $82,2 \%$ responden belum memiliki perilaku penyimpanan makanan yang baik.

Kesimpulan: Sebagian besar responden belum memiliki perilaku mencuci bahan makanan yaitu sebanyak $73,3 \%$ responden tidak memiliki kebiasaan mencuci bahan makanan dan sebagian besar responden belum memiliki perilaku penyimpanan makanan yang baik yakni $82,2 \%$ responden tidak mengetahui cara penyimpanan makanan yang baik.

Kata kunci: Diare, perilaku ibu dan balita, perilaku hidup sehat

\section{DESCRIPTION OF BEHAVIOR HEALTHY LIVING IN WOMEN WHO HAVE CHILDREN IN AREA PUBLIC HEALTH CENTRE UBUD I, GIANYAR, BALI 2014}

\section{ABSTRACT}

Background: Diarrhea is a public health problem in Indonesia. In January to December 2013, diarrhea was among the 10 diseases in Puskesmas Ubud I, which ranks 9th with a number of 687 cases. The prevalence of diarrhea in infants in Puskesmas Ubud I 220 children or 6,1\%.

Methods: This study used a descriptive cross-sectional design. Data were obtained from interviews with a structured questionnaire. Respondents were 45 mothers who has toddler chosen by simple random sampling. Data were analyzed using statistical program and presented in tabular form and narrative.

Results: Most respondents (88.9\%) already have hand washing behavior, but the method used is still much less good. Most respondents do not have a washing behavior as many as $73,3 \%$. As many as $60 \%$ of respondents own behavior wash cutlery and most of the methods used is good. $68,9 \%$ of respondents have a water boiling behavior and methods are good. $82.2 \%$ respondents do not have a good food storage behavior. 
Conclusions: The majority of respondents do not have a washing behavior, as many as $73,3 \%$ of respondents do not have the habit of washing foods and most respondents do not have a good food storage behavior that $82,2 \%$ of respondents did not know how to store good food.

Keywords: Diarrhea, the behavior of mothers and infants, health behavior.

\section{PENDAHULUAN}

Sampai saat ini penyakit diare masih menjadi masalah kesehatan dunia terutama di negara berkembang. Di Indonesia, diare masih merupakan salah satu masalah kesehatan masyarakat utama. Hal ini menyebabkan tingginya angka kesakitan dan menimbulkan banyak kematian terutama pada bayi dan balita, serta sering menimbulkan kejadian luar biasa (KLB).

Berdasarkan profil kesehatan Indonesia 2003, penyakit diare menempati urutan kelima dari 10 penyakit utama pada pasien rawat jalan di Rumah Sakit dan menempati urutan pertama pada pasien rawat inap di Rumah Sakit.

\section{METODE}

Penelitian ini adalah menggunakan desain deskriptif cross sectional.

Populasi target yaitu balita berumur 1260 bulan dengan riwayat diare. Sedangkan populasi terjangkau yaitu balita berumur 12-60 bulan dengan riwayat diare di wilayah kerja Puskesmas Ubud I, Gianyar dari bulan mei hingga oktober 2014. Kriteria inklusi yaitu: balita yang berdomisili di wilayah kerja Puskesmas Ubud I, Gianyar,balita yang masih memiliki ibu. Kriteria eksklusi yaitu: balita yang memiliki ibu yang tidak mampu berkomunikasi dengan baik karena menderita suatu penyakit, balita yang menderita cacat fisik (hidrosefalus, cerebral palsy, atau amputasi anggota gerak), balita yang mengalami suatu infeksi berat lain dalam sebulan terakhir.

Dari rumus diperoleh sampel dalam penelitian ini yaitu berjumlah 45 orang.

Data diperoleh dengan cara teknik wawancara menggunakan acuan kuisioner dan pengamatan langsung. Wawancara dilakukan di rumah responden dengan lama wawancara sekitar 15 menit.

\section{HASIL PENELITIAN}

Karakteristik Balita Diare

Dari 45 sampel balita dengan riwayat diare diperoleh rerata umur balita yaitu 28,5 bulan. Dari tabel 1, dilihat sebanyak27 sampel (60\%) memiliki umur di bawah rerata dari keseluruhan sampel (<28,5 bulan). Berdasarkan jenis kelamin sampel penelitian lebih banyak merupakan laki-laki dibandingkan perempuan dengan presentase 53,3\% sampel laki-laki.

Tabel 1. Distribusi Frekuensi Karakteristik Balita Diare

\begin{tabular}{lcc}
\hline Variabel & Jumlah & $\begin{array}{c}\text { Presentase } \\
\text { (\%) }\end{array}$ \\
\hline Umur $(\mathrm{n}=45)$ & & 60 \\
$\quad<28,5$ bulan & 27 & 40 \\
$\quad \geq 28,5$ bulan & 18 & \\
Jenis Kelamin ( $\mathrm{n}=$ & & 53,3 \\
$45) \quad 24$ & 46,7 \\
$\quad$ Laki-laki & 21 & \\
\hline
\end{tabular}

\section{Karakteristik Responden}

Penelitian ini dilakukan terhadap 45 ibu balita dan semuanya bisa tercakup dalam penelitian. Profil responden berdasarkan umur, dimana diperoleh frekuensi responden tertinggi pada rentang umur $21-30$ tahun $(44,4 \%)$ dengan rata-rata umur 31,02 tahun. Berdasarkan pendidikan, responden memiliki pendidikan yang cukup memadai oleh karena lebih dari setengah responden $(57,8 \%)$ berpendidikan menengah (Tabel 2).

Berdasarkan jenis pekerjaan, 33,3\%. responden bekerja sebagai wiraswasta/dagang dan 26,7 \% tidak bekerja (Tabel 2). Hal ini dilihat dari daerah pariwisata dimana sebagian besar warga bekerja sebagai pedagang, ataupun pengrajin.

Tabel 2. Distribusi Frekuensi Karakteristik Responden

\begin{tabular}{ccc}
\hline Variabel & Jumlah & Persentase (\%) \\
\hline Umur $(\mathrm{n}=45)$ & & \\
$<21$ tahun & 3 & 6,7 \\
$21-30$ tahun & 20 & 44,4 \\
\hline
\end{tabular}




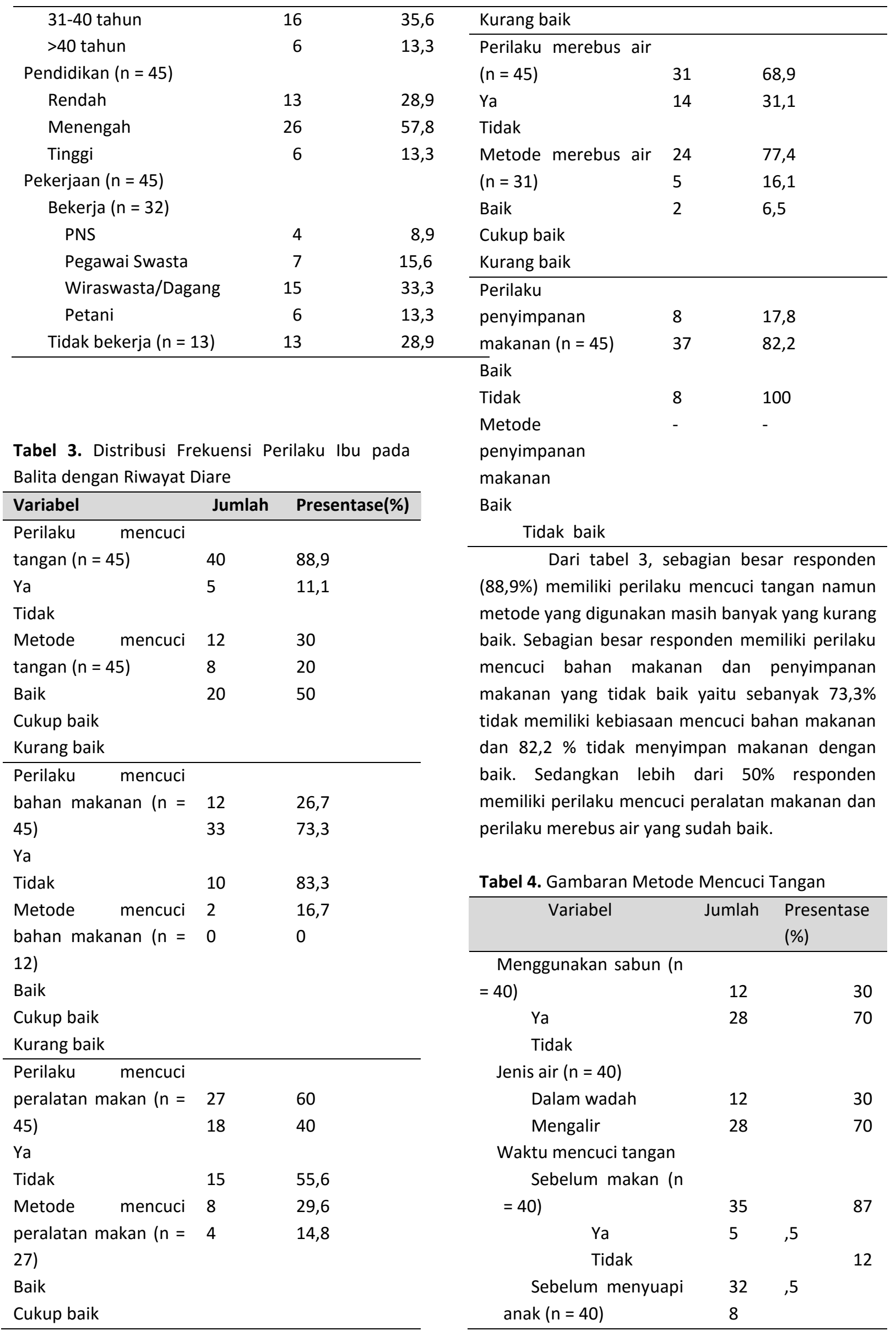




\begin{tabular}{|c|c|c|c|}
\hline $\mathrm{Ya}$ & & & 80 \\
\hline Tidak & 11 & & 20 \\
\hline Sesudah & 29 & & \\
\hline beraktivitas dari luar & & & 27 \\
\hline$(n=40)$ & 10 & ,5 & \\
\hline Ya & 30 & & 72 \\
\hline Tidak & & ,5 & \\
\hline Sebelum & 28 & & \\
\hline menghidangkan & 12 & & 25 \\
\hline makanan $(n=40)$ & & & 75 \\
\hline \multicolumn{4}{|l|}{ Ya } \\
\hline Tidak & & & 70 \\
\hline Sesudah dari toilet & & & 30 \\
\hline \multirow{2}{*}{\multicolumn{4}{|c|}{$\begin{array}{l}\text { atau kamar mandi }(n= \\
40)\end{array}$}} \\
\hline & & & \\
\hline Ya & & & \\
\hline Tidak & & & \\
\hline
\end{tabular}

Dari tabel 4, 40 orang responden yang memiliki kebiasaan mencuci tangan, diperoleh bahwa metode yang digunakan kebanyakan yang kurang baik, hanya $30 \%$ yang menggunakan sabun saat mencuci tangan. Jenis air yang digunakan sudah benar yakni $70 \%$ responden mengaku menggunakan air yang mengalir. Responden sudah mencuci tangan di waktu yang tepat yaitu sebelum makan, sebelum menyuapi anak, dan setelah dari toilet, namun terdapat $72,5 \%$ responden yang tidak mencuci tangan setelah beraktivitas dari luar dan $75 \%$ tidak mencuci tangan sebelum menghidangkan makanan.Dari tabel 5, 12 orang responden yang mencuci bahan makanan, 83,3\% menggunakan air dengan sumber yang baik.

Tabel 5. Gambaran Metode Mencuci Bahan Makanan

\begin{tabular}{cccc}
\hline Variabel & Jumlah & $\begin{array}{l}\text { Presentase } \\
(\%)\end{array}$ \\
\hline $\begin{array}{c}\text { Air yang digunakan } \\
\text { PAM/ledeng } \\
\text { Sumur }\end{array}$ & 10 & & 83, \\
& 2 & 3 & 16, \\
Waktu mencuci & & 7 & \\
bahan makanan & 12 & & 100 \\
$\quad \begin{array}{l}\text { Sebelum } \\
\text { dipotong } \\
\text { Setelah dipotong }\end{array}$ & 0 & & 0 \\
\hline
\end{tabular}

Tabel 6. Gambaran Metode Mencuci Peralatan Makanan

\begin{tabular}{|c|c|c|}
\hline Variabel & Jumlah & $\begin{array}{l}\text { Presentase } \\
(\%)\end{array}$ \\
\hline \multicolumn{3}{|l|}{ Menggunakan sabun (n } \\
\hline$=27)$ & 15 & 55,6 \\
\hline Ya & 12 & 44,4 \\
\hline Tidak & & \\
\hline \multirow{2}{*}{\multicolumn{3}{|c|}{$\begin{array}{c}\text { Memisahkan } \quad \begin{array}{l}\text { bahan } \\
\text { makanan }\end{array} \text { sebelum }\end{array}$}} \\
\hline & & \\
\hline mencuci peralatan makan & 20 & 74,1 \\
\hline$(n=27)$ & 7 & 25,9 \\
\hline \multicolumn{3}{|l|}{$\mathrm{Ya}$} \\
\hline \multicolumn{3}{|l|}{ Tidak } \\
\hline \multicolumn{3}{|l|}{ Menggosok bagian } \\
\hline yang kotor saja $(n=27)$ & 0 & \\
\hline Ya & 27 & 100 \\
\hline \multicolumn{3}{|l|}{ Tidak } \\
\hline \multicolumn{3}{|l|}{ Tersedia tempat } \\
\hline mencuci dan rak $(n=27)$ & 18 & 66,7 \\
\hline $\mathrm{Ya}$ & 9 & 33,3 \\
\hline \multicolumn{3}{|l|}{ Tidak } \\
\hline \multicolumn{3}{|l|}{ Merendam botol susu } \\
\hline \multicolumn{3}{|l|}{ dengan air hangat } \\
\hline setelah dicuci $(n=27)$ & 21 & 77,8 \\
\hline Ya & 8 & 22,2 \\
\hline Tidak & & \\
\hline
\end{tabular}

Pada tabel 6, dapat dilihat dari 27 orang responden yang memiliki kebiasaan mencuci peralatan makanan, sebagian besar sudah menerapkan metode yang baik.

Dari tabel 7, Sebagian besar responden menggunakan sumber air yang baik yakni $61 \%$ air PAM/ledeng, air dalam kemasan 32,3 \% dan lebih dari $70 \%$ responden sudah merebus air sampai mendidih.

Tabel 7 Gambaran Perilaku Merebus Air untuk Minum

\begin{tabular}{ccc}
\hline Variabel & Jumlah & $\begin{array}{c}\text { Presentase } \\
(\%)\end{array}$ \\
\hline $\begin{array}{c}\text { Merebus air sampai } \\
\text { mendidih }(\mathrm{n}=31)\end{array}$ & 24 & 77,4 \\
Ya & 7 & 22,6 \\
Tidak & & \\
Sumber air ( $\mathrm{n}=31)$ & & \\
Dalam & 10 & 32,3 \\
kemasan & 19 & 61,3 \\
\hline
\end{tabular}




\begin{tabular}{llll} 
& PAM/lede & 2 & 6,4 \\
ng & & 0 & 0 \\
& $\begin{array}{l}\text { Sumur } \\
\text { Sumber }\end{array}$ & & \\
lain & & & \\
\hline
\end{tabular}

Tabel 8.Gambaran Metode Penyimpanan Makanan

\begin{tabular}{|c|c|c|c|c|}
\hline \multicolumn{2}{|c|}{ Variabel } & \multirow[t]{2}{*}{ Jumlah } & \multicolumn{2}{|c|}{$\begin{array}{l}\text { Presentase } \\
(\%)\end{array}$} \\
\hline \multicolumn{4}{|c|}{ Tempat meletakkan } & \\
\hline \multicolumn{2}{|c|}{ makanan $(n=45)$} & & 3 & 82 \\
\hline & atas & 7 & \multicolumn{2}{|c|}{2} \\
\hline \multirow[t]{2}{*}{ meja } & & & $\varepsilon$ & 17 \\
\hline & Di dalam & & \multicolumn{2}{|c|}{8} \\
\hline \multicolumn{5}{|l|}{ lemari } \\
\hline \multicolumn{5}{|c|}{ Menutup makanan } \\
\hline \multirow{2}{*}{\multicolumn{2}{|c|}{$\begin{array}{l}\text { apabila diletakkaan di } \\
\text { atas meja }(n=37)\end{array}$}} & & 2 & 67 \\
\hline & & 5 & \multicolumn{2}{|c|}{6} \\
\hline \multicolumn{2}{|r|}{ Ya } & & 1 & 32 \\
\hline & Tidak & 2 & \multicolumn{2}{|c|}{4} \\
\hline \multicolumn{5}{|c|}{ Peralatan yang } \\
\hline digunakan & untuk & & 5 & 20 \\
\hline \multicolumn{2}{|c|}{ menutup ( $n=25$ ) } & & 7 & 28 \\
\hline \multicolumn{2}{|r|}{ Tudung saji } & & \multirow[t]{3}{*}{1} & 52 \\
\hline & Plastik & 3 & & \\
\hline & Kertas & & & \\
\hline
\end{tabular}

Dari tabel 8, sebanyak 37 orang responden $(82,2 \%)$ penyimpan makanan yang tidak baik dengan meletakkan makanan di atas meja. Dari 37 orang responden tersebut sebanyak $67,6 \%$ mengatakan menutup makanan tersebut namun masih banyak yang menggunakan peralatan yang kurang tepat yaitu menggunakan $28 \%$ menggunakan plastik dan 52\% menggunakan kertas sebagai penutup makanan sehingga ada kemungkinan makanan dapat terkontaminasi oleh serangga ataupun debu.

Dari tabel 9, sebagian besar balita (77.8\%) tidak memiliki perilaku mengemut benda.

Tabel9. Gambaran Perilaku Mengemut pada Balita dengan Riwayat Diare

\begin{tabular}{ccc}
\hline Variabel & Jumlah & $\begin{array}{l}\text { Presentase } \\
(\%)\end{array}$ \\
\hline Perilaku mengemut & & \\
benda $(\mathrm{n}=45)$ & 10 & 22,2 \\
Ya & 35 & 77,8 \\
\hline
\end{tabular}

Tidak

PEMBAHASAN

\section{Perilaku Ibu pada Balita dengan Riwayat Diare}

Perilaku ibu selaku care-giver yang paling sering melakukan kontak dengan balita, menjadi salah satu faktor yang menentukan terjadinya diare pada balita. Apabila ibu melakukan perilaku berisiko, maka akan meningkatkan kemungkinan balita untuk terkena diare. Seseorang baru dapat mengubah sikap dan perilakunya untuk hidup sehat setelah memiliki pengetahuan yang baik tentang kesehatan. Begitu pula halnya dalam perilaku pencegahan diare pada balita (Notoatmodja, 2007).

Perilaku Mencuci Tangan pada Ibu dengan Balita yang Mengalami Diare

Pada tabel 5.3 ditunjukkan bahwa sebagian besar responden yaitu 88,9 \% memiliki perilaku mencuci tangan namun metode yang digunakan masih banyak yang kurang baik. Sebanyak 20 dari 40 orang responden menggunakan metode yang kurang baik, 8 orang dengan metode yang cukup baik, dan 12 orang sudah menerapkan metode yang baik. Dari tabel 5.4 dapat dilihat bahwa $70 \%$ ibu yang memiliki balita dengan riwayat diare memiliki kebiasaan mencuci tangan tidak dengan menggunakan sabun. Hal ini didukung oleh penelitian sebelumnya yang mendapatkan bahwa mencuuci tangan efektif mencegah penyakit jika dilakukan secara benar yaitu dengan menggunakan air dan sabun antiseptik yang dapat membunuh kuman, dilakukan pada seluruh bagian telapak dan jari-jari tangan, serta menggunakan air yang mengalir. Mencuci tangan tanpa menggunakan sabun masih menjadi faktor kejadian diare pada balita. Hal ini didukung oleh beberapa penelitian yang juga menemukan adanya hubungan yang signifikan antara perilaku mencuci tangan tanpa menggunakan sabun dengan kejadian diare pada balita dengan ( $p=0.000$ ) (Taosu dan Anyerdy, 2009, Fatmasari, 2008; Warman 2008).

Menurut salah satu studi World Health Organisation (WHO) menyatakan praktek cuci tangan memakai sabun pada lima waktu tertentu, yaitu sebelum makan, setelah buang air besar, sebelum memegang bayi, setelah menceboki 
pantat anak, dan sebelum menyiapkan makanan untuk bayi bisa mengurangi prevalensi diare sampai $40 \%$. Sedangkan pada penelitian ini, pada tabel 5.4 dapat dilihat bahwa masih banyak responden yang tidak mencuci tangan sesudah beraktivitas dari luar rumah dan sebelum menghidangkan makanan. Diperoleh 72,5\% responden mengaku tidak mencuci tangan setelah beraktivitas dari luar dan 75\% tidak mencuci tangan sebelum menghidangkan makanan. Dari hasil ini dapat diketahui perilaku mencuci tangan pada ibu pada balita dengan riwayat diare masih menggunakan metode yang kurang baik karena baru menerapkan sebagian dari cara mencuci tangan dengan benar.

Perilaku Mencuci Bahan Makanan dan Peralatan Makanan pada Ibu dengan Balita yang Mengalami Diare

Perilaku mencuci bahan makanan masih kurang baik pada ibu dengan balita yang mnengalami diare di wilayah kerja Puskesmas Ubud I. Hal ini dapat dilihat dari tabel 5.3 bahwa 73,3\% responden tidak mencuci bahan makanan sebelum dimasak. Sementara hanya $26,7 \%$ responden yang sudah mencuci bahan makanan dengan metode yang baik dan cukup baik. Sumber air yang digunakan untuk mencuci bahan makanan yaitu $83,3 \%$ menggunakan sumber air bersih yaitu air PAM/ledeng. Mencuci peralatan yang digunakan untuk memasak dan makan sangat penting untuk diperhatikan, dan memastikan bahan makanan sudah dicuci dengan air bersih merupakan hal yang penting. Hal ini disebabkan karena sebagian besar kuman infeksius penyebab diare ditularkan melalui jalur fecal-oral.

Sementara itu, lebih dari $50 \%$ responden mencuci peralatan makan setelah digunakan dan metode yang digunakan sudah baik dan cukup baik.

\section{Perilaku Merebus Air pada Ibu dengan Balita yang Mengalami Diare}

Dari penelitian ini didapat bahwa perilaku merebus air sudah dilakukan dengan baik. Sebanyak 68,9\% responden mengatakan merebus air untuk minum dan metode yang digunakan sebagian besar sudah baik. Namun 31\% responden mengatakan tidak merebus air untuk minum karena menggunakan filter/penyaringan air dengan sumber dari sumur maupun PAM/ledeng.
Syarat air minum yakni, air tidak berwarna, tidak berasa, tidak berbau, jernih dengan suhu sebaiknya di bawah suhu udara sehingga terasa nyaman, air tidak mengandung zat kimia atau mineral yang berbahaya bagi kesehatan misalnya $\mathrm{CO}_{2}, \mathrm{H}_{2} \mathrm{~S}, \mathrm{NH}_{4}$, air tidak mengandung bakteri $E$. coli yang melampaui batas yang ditentukan, kurang dari 4 setiap $100 c c$ air. Dalam upaya mengantisipasi penyakit diare, langkah yang harus dilakukan oleh masyarakat adalah memasak air hingga mendidih dan bila mendidih harus didiamkan selama tiga menit.

Hasil studi Taosu dkk (2009) menunjukkan bahwa dengan meningkatkan perilaku pengelolaan air minum yang aman di rumah tangga, kejadian diare akan menurun sebesar 39\%. (Taosu dkk, 2009)

Perilaku Penyimpanan Makanan pada Ibu dengan Balita yang Mengalami Diare

Dari tabel 5.3 didapat bahwa 82,2\% responden memiliki perilaku penyimpanan makanan yang tidak baik yaitu dengan meletakkan makanan diatas meja. Dan kebanyakanmenggunakan peralatan yang tidak baik yaitu dengan menggunakan kertas dan plastik sehingga hal ini dapat menybabkan masuknya bakteri, debu, ataupun serangga sebagai vektor penyebab diare pada makanan.

Berdasarkan jenis pekerjaan, 71,1\%. responden bekerja dan 28,9\% tidak bekerja (Tabel 5.1). Menurut Muhammad Ali (2003), ibu bekerja adalah ibu-ibu yang melakukan aktifitas ekonomi mencari penghasilan baik di sektor formal maupun informal, yang dilakukan secara regular di luar rumah. Sedangkan ibu tidak bekerja adalah ibu-ibu yang tidak melakukan pekrjaan mencari penghasilan dan hanya menjalankan fungsi sebagai ibu rumah tangga saja. Hal ini berarti setengah ibu balita memiliki aktivitas di luar rumah sehingga mengurangi waktu untuk memperhatikan dan mengurusi balitanya dengan baik. Penyimpanan makanan pada ibu yang bekerja bisa dilakukan oleh anggota keluarga lain, ataupun pembantu rumah tangga. Pengetahuan yang kurang baik tentang perilaku penyimpanan makanan yang benar pada orang yang bertugas menyimpan makanan sangat penting untuk mencegah diare. $\mathrm{Hal}$ ini dapat mempengaruhi kejadian diare pada balita. (Ali, 2003) 


\section{Perilaku "Mengemut" pada Balita dengan Riwayat Diare}

Dari hasil penelitian yang dilakukan dari 45 sampel balita dengan riwayat diare diperoleh rerata umur balita yaitu 28,5 bulan. Dari tabel dilihat lebih dari setengah sampel (60\%) memiliki umur di bawah rerata dari keseluruhan sampel $(<28,5$ bulan). Perilaku mengemut benda atau mainan sering dilakukan oleh balita. Sementara itu berdasarkan jenis kelamin sampel penelitian lebih banyak merupakan laki-laki dibandingkan perempuan dengan presentase 53,3\% sampel lakilaki sedangkan jenis kelamin perempuan sebanyak 46.7\%. Anak laki-laki memiliki aktivitas fisik yang lebih tinggi daripada anak-anak perempuan.

Perilaku mengemut benda pada balita dapat merupakan salah satu mekanisme penularan diare yaitu melalui kontaminasi alat-alat/ benda yang tidak terjaga kebersihannya. Kemudian akan terjadi infeksi pada saluran pencernaan anak yang merupakan penyebab utama diare pada anak. Namun pada penelitian ini sebagian besar balita (77.8\%) tidak memiliki perilaku mengemut benda.

\section{KESIMPULAN}

Berdasarkan hasil dan pembahasan maka dapat disimpulkan gambaran perilaku ibu, perilaku balita terhadap kejadian diare di Wilayah Kerja Puskesmas Ubud I meliputi:

1. Sebagian besar responden $(88,9 \%)$ sudah memiliki perilaku mencuci tangan namun metode yang digunakan masih banyak yang kurang baik.

2. Sebagian besar responden belum memiliki perilaku mencuci bahan makanan yaitu sebanyak $73,3 \%$ responden tidak memiliki kebiasaan mencuci bahan makanan.

3. Pada penelitian ini, $60 \%$ responden sudah memiliki perilaku mencuci peralatan makanan dan sebagian besar metode yang digunakan sudah baik.

4. Lebih dari setengah responden yakni $68,9 \%$ responden memiliki perilaku merebus air dan metode yang sudah baik.

5. Sebagian besar responden belum memiliki perilaku penyimpanan makanan yang baik yakni $82,2 \%$ responden tidak mengetahui cara penyimpanan makanan yang baik.
6. Sebagian besar balita (77.8\%) tidak memiliki perilaku mengemut benda.

\section{DAFTAR PUSTAKA}

1. Ali, Muhammad. 2003. Pengetahuan Sikap dan Perilaku Ibu bekerja dan Ibu Tidak bekerja tentang Imunisasi. USU e-Repository.

2. Departemen Kesehatan R I. (2000), Laporan Hasil Survei Angka Kesakitan Diare dan Perilaku Ibu Dalam Tatalaksana Penderita Diare Balita Tahun 2000, Departemen Kesehatan RI, Jakarta.

3. Departemen Kesehatan R I. (2005), Laporan Hasil Survei Angka Kesakitan Diare dan Perilaku Ibu Dalam Tatalaksana Penderita Diare Balita Tahun 2005, Departemen Kesehatan RI, Jakarta.

4. Esrey. 1990. Health Benefits From Improvement in Water Supply and Sanitation. WASH Technical Report No. 66. Arlington, VA.: Water and Sanitation for Health Project.

5. Fathonah, S. Higiene dan Sanitasi Makanan. Semarang: Universitas Negeri Semarang Press. 2005

6. Fatmasari, Heni. 2008. Hubungan Beberapa Faktor Risiko dengan Kejadian Diare Pada Anak Balita di Ruang Rawat inap Puskesmas Kecamatan Jatibarang Kabupaten Brebes .http://digilib.unimus.ac.id. diakses pada tanggal 23 November 2014.

7. Hira, A.M. 2002. Analisis Faktor Resiko terhadap kejadian diare pada anakBalita di Kecamatan bantimurung Tahun 2002: Analisis Faktor KejadianDiare.

8. Kementerian Kesehatan RI. 2011. Siituasi Diare di Indonesia: Pengendalian Diare di Indonesia. Hal.24-25. Subdit Pengendalian Diare dan Infeksi Saluran Pencernaan. Kementerian Kesehatan RI

9. Menteri Kesehatan Republik Indonesia. 2008. Laporan Hasil Riset Kesehatan Dasar (Riskesdas) Nasional 2007. Hal. 106-109. Badan Penelitian dan Pengembangan Kesehatan. Departemen Kesehatan RI.

10. Menteri Kesehatan Republik Indonesia. 2008. Laporan Riskesdas 2007 Provinsi Bali. Hal. 7577. Badan Penelitian dan Pengembangan Kesehatan. Departemen Kesehatan RI. 
11. Notoatmodja S. 2007. IImu Kesehatan Masyarakat.Jakarta: Rineka Cipta.

12. Sarudji, Didik. Kesehatan Lingkungan. Cetakan ketiga. Media Ilmu. Sidoarjo. 2006.

13. Sastroasmoro S, Sofyan I. 2010. Dasar-Dasar Metodologi Penelitian Klinis Edisi ke-3. Jakarta: CV Agung Seto

14. Taosu; Anyerdi, Stefen. 2009. Hubungan Sanitasi Dasar Rumah dan Perilaku Ibu Rumah Tangga dengan Kejadian Diare pada Anak Balita. ADLN Perpustakaan Universitas Airlangga.

15. Warman, Yance. 2008. Hubungan Faktor Lingkungan, Sosial Ekonomi dan Pengetahuan Ibu dengan Kejadian Diare Akut Pada Balita di Kelurahan Pekan Arba Kecamatan Tembilahan Kabupaten Indragiri Hilir. diakses pada tanggal 23 November 2014.

16. World Gastroenterology Organisation Global Guidelines, 2012. Acute Diarrhea in Adults and Children: a Global Perspective. http://www. Worldgastroenterology.org/assets/export/use rfiles/Acute\%20Diarrhea_long_FINAL_120604. pdf. Diunduh pada 22 November 2014, hal.4-6 